\title{
Domestic Workers and the Right to Primary Education in Ethiopia: Evaluating the Adequacy of the Legal Framework
}

\author{
Enguday Meskele Ashine (LLM) \\ Lecturer in Human rights law and International Law@Wolaita Sodo University, School of Law, Wolaita Sodo, \\ Ethiopia. P.O. Box 138
}

\begin{abstract}
In Ethiopia, recognition is given for domestic worker's rights in different dimensions. However, domestic workers are most vulnerable groups for abuses and violation of their human rights. In addition; the right to education of domestic workers has been grossly neglected by the state. Arguing that the policy and legislative initiatives are a prerequisite to the realization of the right to education of domestic workers, the paper explores the legal gaps in realization of domestic workers right to education.. Furthermore, the study develops an analytical framework for the right to education of domestic workers, derived from Ethiopian ratified international and regional legal instruments which guarantees the right to domestic workers.
\end{abstract}

Keywords: Domestic workers, Education, Human rights, Ethiopia

DOI: $10.7176 / \mathrm{DCS} / 9-6-02$

Publication date:June $30^{\text {th }} 2019$

\section{Introduction}

Domestic work is a predominately female-dominated sector that is poorly regulated and often unprotected by labour law or outside the scope of labour legislation and face serious decent work deficits. Moreover, issues of gender also come into play heightening the weak bargaining power of domestic workers. Their isolation and vulnerability as workers is made more complex by their invisibility in private homes and their dependence on the good will of their employers. ${ }^{1}$ According to the most recent global and regional estimates produced by the ILO, at least 52.6 million women and men above the age of 15 were domestic workers in their main job. This figure represents some 3.6 percent of global wage employment. Women comprise the overwhelming majority of domestic workers, 43.6 million or some 83 per cent of the in the world. ${ }^{2}$

Around 70 per cent of domestic workers across Africa are women. In Africa, $13.6 \%$ of all female wage employees are domestic workers. Being an important entry point for women into the labour market, improving working conditions in the sector has broader ramifications for greater gender equality in many countries. ${ }^{3}$ Even if not an exact count for different factor all over the world, in Ethiopia also women share more than $90 \%$ of total domestic worker in the entire country. ${ }^{4}$ Yet in today's society, domestic work is vital for the economy outside of the household to function. The current levels of growth and welfare would not be the same without the contribution of domestic workers. The massive incorporation of women in the labour force, the ageing of societies, the intensification of work and the lack and inadequacy of public policy to facilitate the reconciliation of family life and work clearly underpin this trend. Most domestic workers come from poor households and have generally low levels of education and few marketable skills, other than their skills in keeping house and caring for others. Alongside working long hours for little or no pay, many suffer physical and sometimes sexual abuse, are denied their right to go to school. ${ }^{5}$ Convention No. 189 and Recommendation No. 201, adopted by International Labour Conference in 2011 and gave a clear message about Domestic workers, like other workers, have the right to decent working and living conditions. The Convention provides for minimum protection of domestic workers, this enables domestic worker to develop themselves, including education, in several aspect. ${ }^{6}$

\section{Definition of domestic work}

Domestic worker Convention no 189/2011 defines "domestic work" under Art. 1(a), as "work performed in or for a household or households". Domestic work may involve a range of tasks, including cooking, cleaning the house, washing and ironing the laundry, general housework, looking after children, the elderly or persons with disabilities, as well as maintaining the garden, guarding the house premises, and driving the family car. A "domestic worker" also defined in Convention No. 189 under Art. 1(b) as "any person engaged in domestic work within an employment relationship. This definition includes domestic workers engaged on a part-time basis and those working for multiple employers, nationals and non-nationals, as well as both live-in and live-out domestic

\footnotetext{
${ }^{1}$ Asha D'souza, moving toward decent work for domestic worker, $17 \mathrm{ff}, 2010$.

2 .www.ilo.org/publns, decent decent work for domestic worker,29,2011.

${ }^{3}$ www.au.int, special initiative on domestic worker in Africa. 16,2015.

${ }^{4}$ Helen Schwenken ET AL, domestic worker count, 10ff, 2011.

5 .ITUC action guide, decent work, decent life for domestic worker, 4ff, 2010

${ }^{6}$. supra not 2 pp11
} 
workers. The employer may be a member of the household for which the work is performed or an agency or enterprise that employs domestic workers and makes them available to households. The Convention specifies under Art.1(c) that "a person who performs domestic work only occasionally or sporadically and not on an occupational basis is not a domestic worker". ${ }^{1}$

\section{Protection and recognition to the right to education under international instrument}

The right to education it is unique in nature because it empower individual to exercise other civil, political, economic, social and cultural rights. Education gives people the knowledge and skills they need to live better lives. It can boost productivity and open doors to jobs and credit. Poverty is one of the main reasons children are being left out of school. Right to education has been firmly enshrined in the following every major human right instrument; ${ }^{2}$

\subsection{Universal declaration of human right 1948}

UDHR is the predecessor to recognize the majority of human rights and it is not an exception to protect and recognize the right to education to everyone at the first blank. Under art. 26 expressly provide "everyone has the right to education" the wording of the provision "everyone" refers the principle of universality because everyone entitled to the right to education without making any reference to sex, age, colour, religion, ethnicity, culture, economic status and other factors. So art 26 commensurate with art 2 of the declaration, relatively addresses the right to education to domestic workers. ${ }^{3}$

\subsection{UNSECO convention against discrimination in education 1960}

UNSECO is the most specific convention against discrimination in education, under art 1, 2, and 3 provide a legal protection for the right to education to all, against any kind of discrimination based on race, colour, sex, language, religion, political or other opinion, national or social origin, economic condition or birth, has the purpose or effect of nullifying or impairing equality of treatment in education is prohibited. Right to education must be inclusive and accessible to all, in law as well as in fact. UNSECO convention result a clear improvement on the elimination of any kind discrimination against marginalized group for different reason. According to UNSECO convention, discrimination for whatever reason is a violation of the right to education. But this does not to mean that any difference in treatment will result discrimination (for e.g. affirmative action) In particular, the Convention aims at eradicating practices of depriving any person or group access to education, of limiting any person or group to education of an inferior standard, of maintaining separate educational systems for any person or group and of imposing on any person or group conditions which are incompatible with human dignity. ${ }^{4}$

\subsection{International convention on economic, social and cultural right 1966}

Right to education is under the category of socio- economic right, for that reason a due emphasis is given, under ICESCR. Right to education recognized and protected under ESCR, with the same tone of UDHR. ICESCR under art 13 specifically provide the right to education, which contain 4 sub art with detail about the right to education. ICESCR is also a guarantee to domestic worker to claim the right to education because it include all individual to access education without the need to made distinction based on, particularly, gender and economic status. According to General Comment No. 13/99 on the Right to Education, impose three types of obligations on States: The obligation to respect requires States to avoid measures that hinder or prevent the enjoyment of the right to education. The obligation to protect requires States Parties to take measures that prevent third parties from interfering with the enjoyment of the right to education. The obligation to fulfill incorporates both an obligation to provide and to facilitate. ${ }^{5}$

\subsection{Convention on the elimination all forms of discrimination against women 1979}

Girls and women constitute the majority of out-of-school children and illiterate adults as their learning opportunities are compromised by a number of in- and out-of-school barriers. They also represent the majority of people living in poverty, are subject to gender-based discrimination and violence and are less likely to have access to services including education. Gender inequalities manifested in all aspects of education process (e.g. access, retention, completion, treatment, learning outcomes and education). Achieving gender equality in education necessitates an approach that equally empowers male and female learners, facilitating access to, retention in and completion of education for all. Gender equality to, in and through education requires action at

\footnotetext{
${ }^{1}$ Mieke verheyde, commentary on UNCRC of art 28, 49, 2006.

2. Www. Unseco.org/80, education count toward millennium development goal, 19ff, 2011

${ }^{3}$ Art 26 of UDHR expressly recognize the right to education,

4 . supra note $7, \mathrm{pp} 12$

5. Www. Unseco.org/80, right to education law and policy review,39,2014.
} 
multiple levels within and outside the education system. ${ }^{1}$ CEDAW generally aimed to preserve gender equality but they did not stop on the avoidance of discrimination against women rather they extend, specifically, up to the right to education. Art 10 specifically state that;

States Parties shall take all appropriate measures to eliminate discrimination against women in order to ensure to them equal rights with men in the field of education and in particular to ensure, on a basis of equality of men and women. Art 10 contains $7 \mathrm{sub}$ art which deal the right to education to women in detail. CEDAW is the most specific convention which deals with particularly with women right so it is more appropriate and relevant to subject matter of female domestic worker than the other covenants. ${ }^{2}$

\subsection{Convention on the right to child 1989}

Article 28 of the CRC repeats most of the education rights guaranteed in the above mentioned International human Rights instruments. The article is in particular phrased in line with Article 13 of the CESCR. The CRC does, however, not merely copy the existing international education rights law but inserts a new dimension to it: education should be child-centered and child-friendly in both a protective and an empowering way. The CRC hence reconceptualised the existing international education rights law from the child's perspective. The text of Article 28, referring to 'the child' as holder of the right to education and omitting a reference to the traditionally recognized parental right to respect for their religious and philosophical convictions in the education of their children, clearly proves this new dimension. In addition to the new dimension it puts in existing education rights, the CRC broadens the bindingness of international provisions on the right to education. ${ }^{3}$

\subsection{ILO convention on minimum age of employment no.138/1973}

ILO convention on minimum age, provide a conduesive environment on the protection of the right to education, even if did not deal with literally the right to education but substantially it assures the right to education through the determination of minimum age, since it eliminate the possibility of work to children before they complete their compulsory primary education. As we all know employment have a direct/negative impact on the education of child because, specially, worst type of labour affect the mental and physical well being of the child and a child became incompetent to entertain the educational aspect. ${ }^{4}$ The convention, under art 2(3) states that:

The minimum age specified in pursuance of paragraph 1 of this Article shall not be less than the age of completion of compulsory schooling and, in any case, shall not be less than 15 years. So ILO convention guarantees the right to education for child particularly young female will be saved from exploitation before completing their compulsory education. ${ }^{5}$

\section{Protection to the right to education under National legislations and policies}

All most the majority of international human right instruments were ratified by Ethiopia, as a matter of fact and law, after ratification, obliged to take necessary step to implement the instrument, particularly to enshrine the content of the convention with in national legislations and policies. So the following national legislations and policies could be a result of accepting international conventions.

\subsection{FDRE CONSTITUTION of 1995}

FDRE constitution under chapter three incorporate almost all human rights in a general manner

When we came to the right to education it is not incorporated in a clear manner, because even there is no single provision which deals specifically the right education. Since right to education is fundamental human right, it's better to give the desired place as a constitutional right. Especially under art35 there is no even single word which refers right to education, so it is difficult to women to entertain the right to education as a constitutional right but even if not a specific as to the right to education art 41(3) provide right to access public service."Every Ethiopian national has the right to equal access to publicly funded social services." So We can interpret the provision as, public service, will include educational service. And also under art 41(4) oblige government to provide education service as country's resource permit. ${ }^{6}$

As to the right to child education art 36(1) (d) and (e) indirectly assure the right to education to children. Art 36(1) protect children from engage on worst form of labour because of it is harmful to their education. Art 36(1) (e) also assures the right to education to the children through following protective approach, which prohibit corporal punishment or cruel, inhuman and degrading treatment against any child as a disciplinary measure in school. As to this point Art 36(1) (e) of the constitution directly reflects the content/idea of art 28(2) of the CRC

\footnotetext{
${ }^{1}$ Supra note 11, pp39.

${ }^{2}$ Art 100 f convention on elimination of all forms of discrimination against women ,specifically deals with women education right.

3 . Supra note 7, pp49.

${ }^{4}$ ILO convention no 139/73 provide minimum age of employment of 15 years, so signatory state can't minimize from that limit.

5 .international labour org., regulation of domestic worker in Indonesia, 19,2006.

${ }^{6}$ Art 41(4) the constitution the only provision which clearly deal about the right to education
} 
which enshrined with protective and empowering approach. ${ }^{1}$

Generally art 25, 35(1), 36(1)(d) and (e), and art 41(3)(4) could be read together as guaranteeing that the right to education in general and the right to education to female domestic worker in particular are protected and recognized under FDRE constitution, art25 play pivotal role for the inclusion of female domestic worker since the provision prohibits any kind of discrimination, in our case, based on gender and economic status. ${ }^{2}$

\subsection{The Labor Proclamation of Ethiopia Proclamation No. 377/2003}

Even if Ethiopian employment law expressly exclude domestic work from its ambit under art 3(d) but it stipulates, which is relevant to young female domestic worker, the minimum age for employment as 14 years. Children below the age of 14 are not allowed to work at all whether in formal employment or in domestic worker. According to the proclamation the 14 years age is put as a bottom line for the labor market in the country. Art 89(2) state that; it is prohibited to employ persons less than 14 years of age. ${ }^{3}$ The exclusion of domestic work from the ambit of labour law is contrary to CEDAW because under Article 15(3) demand to abolish "all other private instruments of any kind with a legal effect which is directed at restricting the legal capacity of women shall be deemed null and void". 4

\subsection{National education and training policy 1994}

The Education and Training Policy of 1994 emanates from a national study conducted to identify the constraints to universal education in Ethiopia. This study pointed to access, equity, efficiency and quality as the four challenges to be solved. But when we came to the content of the policy does not clearly incorporate provision as to the right to access education to women particularly. ${ }^{5}$ Under General Objectives no.2.1.1 state that. Develop the physical and mental potential and the problem-solving capacity of individuals by expanding education and in particular by providing basic education for all. Even if not explicit the policy document also enshrined access to education to all (including domestic worker) ${ }^{6}$

\subsection{The National Women policy (Women's Policy) 1993}

The Policy has been formulated to focus on what the Government ought to do for women, and what women must do for themselves through their own free associations, as well as to show the relationships between the two. The policy document contain several specific objective, the important one is the objective; To facilitate conditions conducive to the speeding up of equality between men and women so that women can participate in the political, social, and economic life of their country on equal terms with men. The policy document is a document predominantly enshrined with the concept of equality, since it is important to rectifying historically unjust status existed between men and women. Based on the principle of equality, women's policy also important to support the right to education of female domestic worker. ${ }^{7}$

\section{5 "Education for all" as contemporary protection movement}

Not only laws that protect the right to education for individuals but sometimes government program may play a vital role on the protection of right to education. The Education for All (EFA) movement is a global commitment to provide quality education for all children, youth and adults. It aims to achieve six key education goals by 2015 , which relate to: early childhood care, primary education, youth and adult learning, literacy, gender equality and education quality. ${ }^{8}$

Ethiopia also were not an exception to "education for all" goal by Ensuring that by 2015 all children, particularly girls, children in difficult circumstances and those belonging to ethnic minorities, have access to and complete, free and compulsory primary education of good quality.

Parity in enrolment ratios at both the primary and secondary levels was singled out among all EFA goals to be achieved by 2015. With that early deadline missed, there has been progress towards this goal since, but the achievement of parity remains elusive. ${ }^{9}$

However, millions primary school-aged children were not in school. Millions more start primary school only to drop out before completing the last grade. According to preliminary estimates carried out by the UNESCO Deep-rooted inequalities linked to wealth, gender, ethnicity, language and location are still major

\footnotetext{
${ }^{1}$ Art 36 , indirectly provide protection as to education.

${ }^{2}$ Under FDRE constitutional guarantee will be ascertained through the cumulating of several provision.

${ }^{3}$ A study on the situation of child labour in Ethiopia,20,2009.

${ }^{4}$ Kidist Mulugeta, velnerablity, legal protection and working condition of domestic worker in Addis Ababa ,12ff, 2012.

5 .efa2015review@unseco.org, education for all national review, 19, 2015.

${ }^{6}$. Ministry of education, the education and training policy and its implementation, 117,2015.

${ }^{7}$.women's policy of 1993 .

8. Supra not 8 ,pp $19 \mathrm{ff}$

${ }^{9}$. supra note 22 , pp $19 \mathrm{ff}$.
} 
barriers to universal primary education. ${ }^{1}$

Now the globe changes its direction to Ensuring equitable and inclusive quality education and lifelong learning for all by 2030 . But the question is this implementable at national level as to domestic worker without having law that governs their working condition? ${ }^{2}$

\section{Factual inaccessibility of education to domestic worker in Ethiopia}

As we discuss in the preceding topics, the right to education properly addressed at international as well as national level through the concerned legal instruments especially under international human right documents. Even if not conclusive Ethiopia also addressed the right to education to all individual without discrimination, that means female domestic worker also legally entitled to access education as any individual. Human right by its nature is not only legal right but also a factual right, so the government should obliged to assure the factuality of the given recognition and protection, unless the existing law became a paper tiger. When we came to the factuality aspects of access to education for domestic worker, it's better to relate with the existence of legal frame work for domestic work. Domestic work in Ethiopia is not only invisible and private sector but also it is systematically marginalized field because it exclude from labour legislation. ${ }^{3}$

In 2011 ILO, in addition to the existence of other related conventions, promulgate independent convention no.189/2011, which deals, exhaustively, with decent working and living condition of domestic worker and provide minimum standard to the signatory state. ${ }^{4}$ the neighbor South Africa is emerging as the world leader in protecting the welfare of those who undertake domestic work. For South Africa, the issue of domestic work is linked closely to racial issues - almost all domestic workers are black South Africans, and many employers are white. ${ }^{5}$ The only legal document that addresses domestic workers in Ethiopia is Civil Code of 1960s. A separate section in the Code deals with the contracts of domestic servants living in their employer's home. Totally the section contain 4 provision mostly deals with contract of work but does no incorporate specifically minimum standard of working condition like working hours, job description, minimum wedge, and so on. As to this law its existence by itself is good but not competent to address decent working condition at all. ${ }^{6}$ It is enough to see only two facts to know the impact of absence adequate legislation as to domestic workers on the right to education, fact one absence of working hour, in south Africa working hour is $45 \mathrm{hrs}$ in a weak but in Ethiopia there is no such types of limit, for that matter domestic worker could not have, let alone access to education, fixed rest time and they expect to respond every order in all time. absence job description also have the same impact, because the existing trend in Ethiopia is general home work with no specification as to the types and size of work, so the worker need to cover all types of work with in the household. so there is no time and strength to go to school. The second fact is absence of minimum wedge, in may recent experience I observe 50 birr payment in a month which is very imbalanced from fulltime work, most of employee leave their home and education because of poverty, let alone to cover cost of education they can't cover the cost of maintenance/livelihood, so fixing the minimum wedge will empower, specially female domestic, financially that mean they can afford cost of education in addition to other costs. ${ }^{7}$

In general absence of adequate legal framework is the major factor for domestic worker not to access education because their chance is depend on the willingness of their employer. ${ }^{8}$

\section{Conclusion and recommendation}

When we talk about domestic worker, it is talking about millions of women because $83 \%$ of the forces are women. Legally speaking Ethiopia government provides access to education to all, at the same time it prohibit any kind of discrimination based on different factors. But when we evaluate the practicability of the protection on domestic worker, it is impossible to domestic workers to benefit from such protection as of right because domestic workers needs at first place decent working and living condition, since absence of such protection, through adequate legislation, will results, directly, the violation of the right to access to education. On the existing situation it is impossible to domestic worker to go to school because there is adequate legislation and their education directly conflict with the interest of their employer. So Ethiopian government should take the following appropriate steps toward domestic workers;

1. while Ethiopia were a member of ILO and making several efforts toward the equality of women at national level it is not appropriate to left behind for several years without ratifying ILO domestic workers convention no 189/2011, so it is the first step to Ethiopia to ratify the convention.

\footnotetext{
.supra note 8 , pp 19.

. supra note 22 , pp 17

, even if Ethiopia provide legal protection as to the right to education, practically can't benefit domestic workers.

. supra note 7,pp49

${ }^{5}$ Supra note $16, \mathrm{pp} 27$.

${ }^{6}$. Supra note $21, \mathrm{pp} 12$.

${ }_{8}^{7}$ Generally decent working and living condition create conducive environment for the right to education to be implemented.

${ }^{8}$.supra note 11 , pp $39 f f$.
} 
2. Ratifying ILO convention no. 189/2011 will not do nothing by itself, unless Ethiopia government make one more step toward enshrining the convention on national legislation, so proclamation no 377/2003 should amend so as to provide decent working and living condition to domestic worker.

3. In Ethiopia there is deep rooted societal problem toward domestic worker, so the government should make effort toward behavioral change of the society through awareness creation. 